\title{
Notes on some grasses III
}

\author{
by Tuguo TATEOKA*
}

館岡曹緒* イネ科杂倠記, III

Received August 15, 1956

5. Affinities of the genus Brylkinia.-Brylkinia is a monotypic genus including B. schmidtii Ohwi (=B. caudata Fr. Schm.) which inhabits Japan, Saghalin, South Kurile Islands and Manchuria. Bentham (1881) and Hackel (1887) placed it near Pleuropogon and Uniola which were assigned to Festuceae-Festucinae. Pilger (1954) transferred Pleuropogon to Festuceae-Glyceriinae, and retained Brylkinia in Festucinae. Ohwi (1942) proposed to treat Brylkinia as an independent subtribe, Brylkininae in the Meliceae. The characteristics of chromosomes and leaf structure of $B$. schmidtii have never been studied. In the present paper the results of their investigation and also considerations on the affinities of the genus are presented.

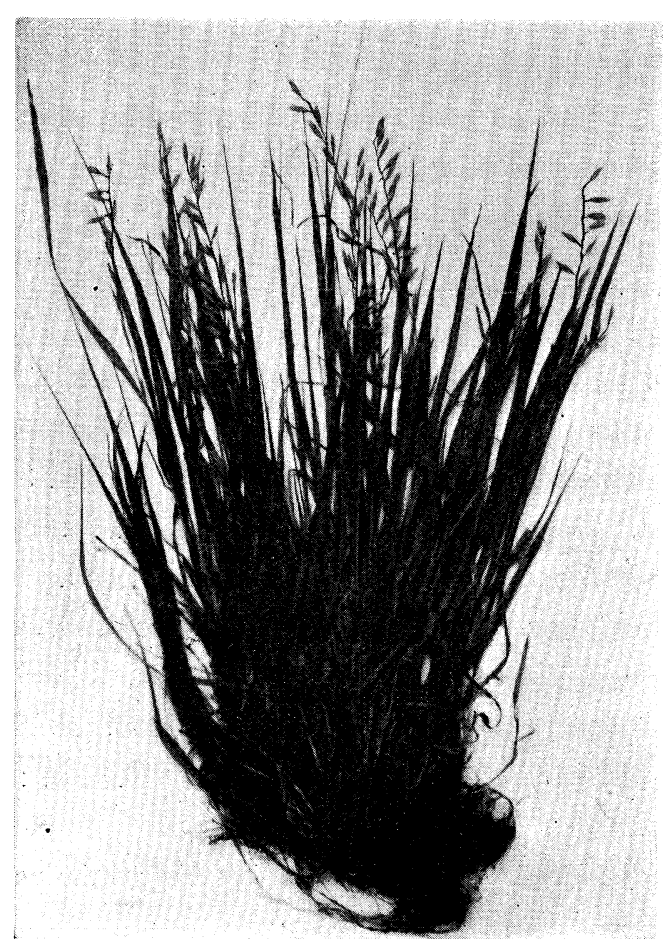

Fig. 1. Brylkinia schmidtii Ohwi

Chromosomes ${ }^{1}$-Materials for chromosome observation were collected at Mt. Mitsutôge, Yamanashi Pref., and Mt. Yatsu and Kamikôchi, Nagano Pref. Invariably in root tip cells forty small chromosomes were found. One pair of Sat-chromosomes was observed (Fig. 1,2). The basic chromosome number is assumed to be ten.

Leaf structure-No bicellular hairs could be found either in the upper or lower epidermis. Siliceous cells show a rectangular shape and wavy contours (Fig. 2, III). In the upper epidermis unicellular hairs are found; they do not possess a sheath of epidermal cells at the base. A mechanical cell layer surrounds the vascular bundles, and the chlorophyll tissue is uniformly distributed between the bundles (Fig. 2, II). This cleary

* National Institute of Genetics, Mishima, Shizuoka Pref. 国立遺伝学研究所

1) The method of chromosome observation was as follows. Root tips were directly fixed at the habitats in Navashin solution. They were later dehydrated, embedded in paraffin and cut at 15 micra. Gentian violet method was used for staining. Chromosome figures were drawn. with the aid of an Abbe drawing apparatus. 
shows that the characteristics of leaf structure of $B$. schmidtii fall into the Festucoid type.

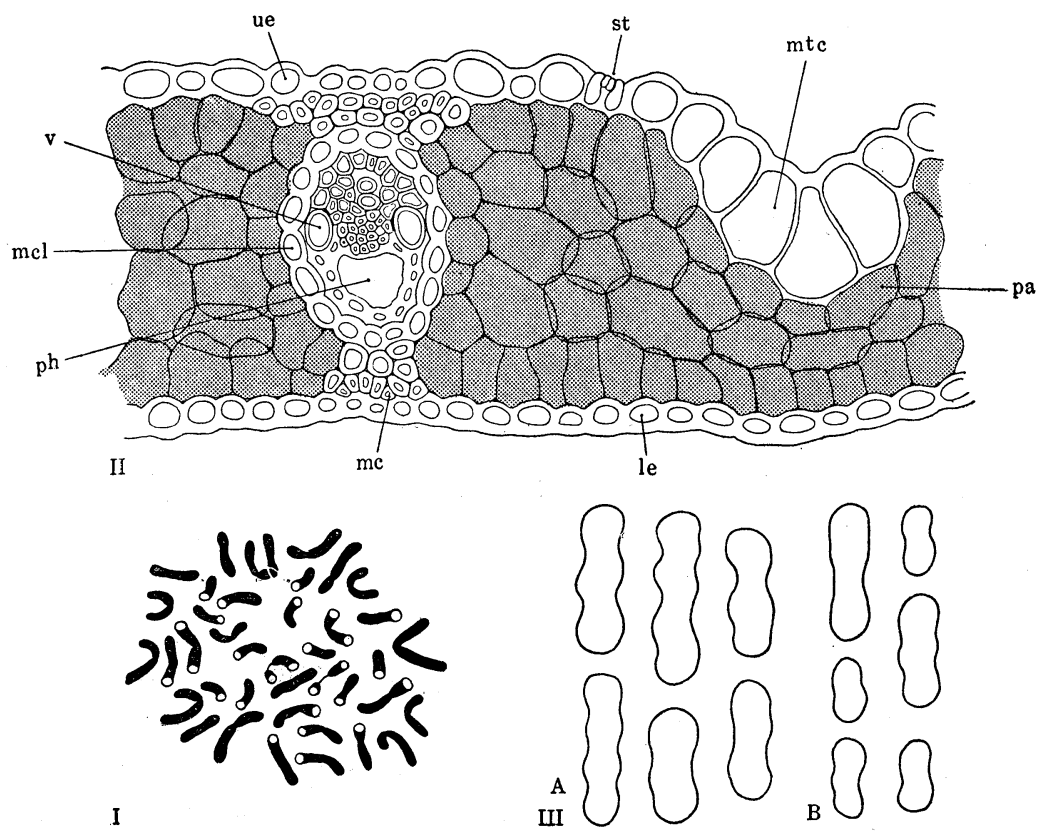

Fig. 2. Brylkinia schmidtii Ohwi. I. Somatic chromosomes $\times 2000.2 \mathrm{n}=$ 40. II. Transverse leaf section $\times 300$. le-lower epidermis. mc-mechanical cell. mcl-mechanical cell layer. mtc-motor cell. pa-parenchyma. phphloem. st-stoma. ue-upper epidermis. v-vessel. III. Siliceous cell $\times 600$. A-upper epidermis, B-lower epidermis.

Consideration-Concerning the chromosome number and their size, B. schmidtii is evidently different from typical members of Festuceae-Festucinae. The latter has the basic chromosome number of seven and large ( medium) sized chromosomes, while Brylkinia is characterized by small chromosomes of basic ten. Brylkinia and Uniola which are erroneously placed in Festuceae-Festucinae have several characteristics in common such as a reduced lower floret, a compressed spikelet, manynerved and winged lemma, etc. However, the two genera are obviously different in the characteristics of chromosomes, leaf structure and endosperm starch. Brylkinia has $\mathrm{b} 10$, while Uniola has $\mathrm{b}=12$; characteristics of leaf structure of Brylkinia are festucoid, but those of Uniola are panicoid; starch grains of endosperm of Brylkinia are compound, while those of Uniola are large, round, and simple. Considering these differences, the two genera cannot be closely related. As mentioned above, Ohwi (1942) included Brylkinia in Meliceae as an independent subtribe. Meliceae, according to Ohwi (1. c.) contains the genus Glyceria, but Melica and Glyceria should be separated having different chromosome characteristics. Chromosome number and size of Glyceria are in good accord with those of Brylkinia; 
$\mathrm{b}=10$ and small size. Also Festucoid type of leaf structure and compound endosperm starch grains are the same in the two genera. It seems to be correct that Brylkinia occupies an intermediate position between Glyceria and Uniola.

6. Systematic problem of the genus Diarrhena.-The genus Diarrhena includes a few species which are distributed in East Asia and one American species, $D$. americana Beauv. Two closely related species, $D$. japonica Franch. et Sav. and $D$. fauriei (Hack.) Ohwi are found in Japan. Chromosomes of Diarrhena have not been examined up to the present. The characteristics of them and leaf structure are reported below for the Japanese species.

Chromosomes-D. japonica was collected at Yugashima, Izu Pennisula, Shizuoka Pref., and $D$. fauriei was obtained from Nagawado (near Kamikôchi), Nagano Pref. In both species, thirty eight small chromosomes were found in root tip cells (Fig.3, IA, IIA).

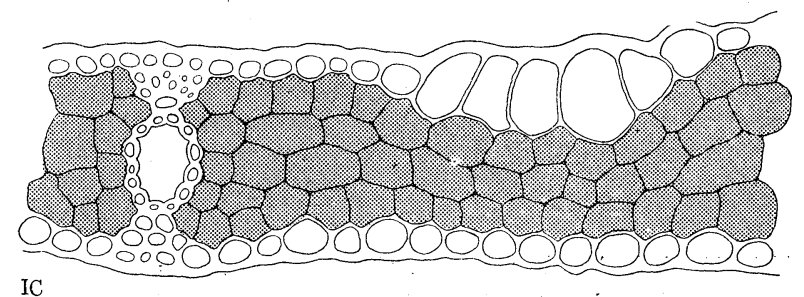

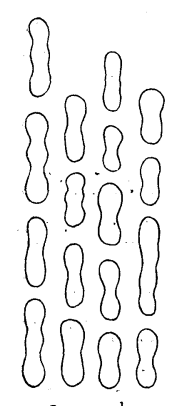

IB
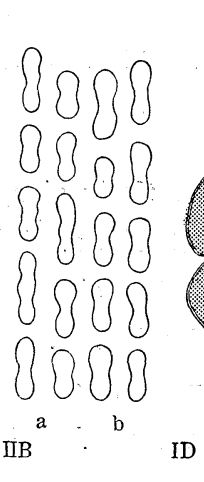

ID
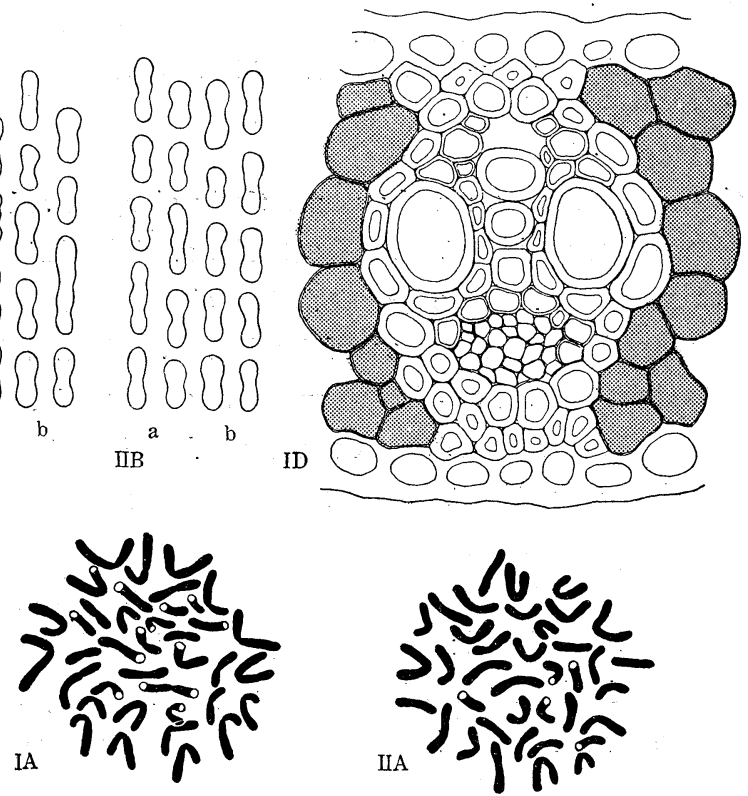

Fig. 3. I. Diarrhena japonica Franch. et Sav. II. $D$. fauriei Ohwi A. Somatic chromosomes $\times 2000$. I and II $2 \mathrm{n}$ $=38$. B. Siliceous cells $\times 300$. a-upper epidermis, b-lower epidermis. C, D. Transverse leaf section $\mathrm{C} \times 300, \mathrm{D} \times 375$.
Leaf structure-In the epidermis of the two species no bicellular hairs were found. Siliceous cells are of rectangular shape and wavy contours, giving a dumbbell appearance to short cells (Fig. 3, IB, IIB). In transverse leaf section, a mechanical cell layer surrounds the vascular bundles and chloroplasts are uniformly distributed throughout the mesophyll (Fig. 3, IC, ID). In respect to the shape of siliceous cells, Diarrhena is intermediate between the Festucoid and the Panicoid type. Put, on the whole, the characteristics of leaf structure of Diarrhena may be regarded as those of Festucoid type.

The systematic placing of Diarrhena is very confused. Bentham (1881) included this 
genus in Festuceae-Melicinae, and remarked that Diarrhena was a very closely related genus to Melica but different from it in the three-nerved and hardened lemma, large grains and two or one stamens. Bentham's view was followed by Hackel (1887). Hitchcock (1935) assigned Diarrhena to Festuceae, but placed it near Molinia, not Melica. Pilger (1954) ascribed Molinia to Arundineae and Diarrhena to Festuceae-Festucinae. Ohwi (1941) pointed out the following common characteristics in Diarrhena and Phaenosperma: lemma three-nerved, glabrous except for the nerves, awnless, rather firm; glumes and lemma involute in immature spikelets; grains large. In addition to the two genera, Molinia, Moliniopsis and Hakonechloa were included in Phaenospermeae by Ohwi (1942). He divided phaenospermeae in three subtribes; Phaenosperminae-Phaenosperma Diarrheninae-Diarrhena, MoliniinaeMolinia, a. o.

The basic chromosome number of Diarrhena is uncertain. The chromosome number of $2 \mathrm{n}=38$ found in $D$. japonica and $D$. fauriei is very unusual in grasses. As basic numbers, 5(10), 6(12), 7, 8, 9 and 11 occur in Poaceae. The number of thirty eight in the two species is assumed to have been produced secondarily from one of the basic numbers indicated above. The small Diarrhena chromosomes are different from the large chromosomes found in typical members of Festucinae. The chromosomes of Poa are somewhat shorter and narrower than those of typical

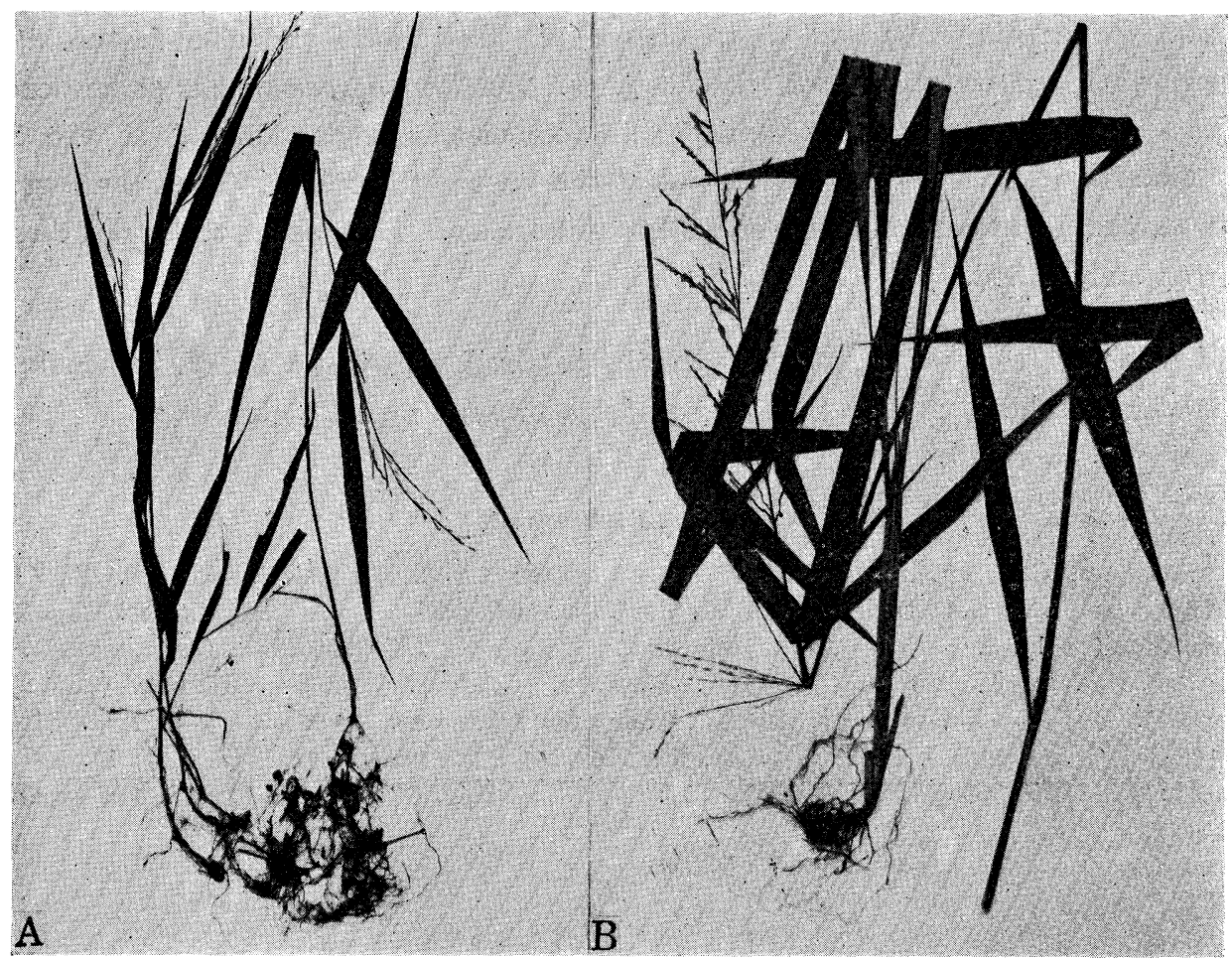

Fig. 4. A. Diarrhena japonica Franch. et Sav. B. Phaenosperma globosum Munro 
members of Festucinae showing a similarity to Diarrhena chromosomes, but Poa is characterized by the basic number of seven. The chromosomes of Melica are somewhat larger and wider than those of Diarrhena. Agrosteae, Phalarideae, Triticeae, Festuceae, etc. which have large ( $\sim$ medium) chromosomes and seven as basic number and a leaf structure of Festucoid type have the center of distribution in the Mediterranean region (cf. Tateoka 1956a, 1956b, 1956c), 1956d, 1956e). The present author is of the opinion that these tribes have a monophyletic origin, and established for them the group Eu-festuciformes. Although Diarrhena is festucoid in leaf structure, this genus cannot be included in Eu-festuciformes group. Because not only distinctive features of external morphology, such as 3-nerved lemma, large beaked grain, 2 opposite stamens, but also the small size of chromosomes are in disagreement with the characteristics of the Eu-festuciformes group. Moreover, the distribution of Diarrhena species does not coincide with that of Eufestuciformes group. Therefore, it is reasonable to separate Diarrhena from Festuceae.

The characteristics of leaf structure in Molinieae are different from those of Diarrhena showing threadlike bicellular hairs and an outer bundle sheath which does not contain chloroplasts surrounding the vascular bundles (cf. Tateoka 1956f). In spite of such differences, Diarrhena and Molinieae have some characteristics in common; the uniform distribution of chlorophyll tissue, small chromosome size, 3-nerved lemma, etc. Phaenosperma and Diarrhena share several common characteristics concerning external morphology (cf. Ohwi 1941) and also festucoid leaf structure and the small size of chromosomes. But Phaenosperma has some peculiar characteristics in external morphology; 3-lodicules, glumes adhered at the base, leaf blades with petiole-like base found at the base of the culms. Thus, these genera show several points of similarity as well as difference. They seem to be not directly but remotely allied.

I wish to express my cordial thanks to Dr. J. Ohwi and Dr. Y. Takenaka for their valuable helps during the course of the present investigation.

\section{Literature cited}

1. Bentham, G., Jour. Linn. Soc. 19: 14-134 (1881). 2. Hackel, E., Nat. Pfl. II 2 (1887). 3. Hitchcock, A. S., U. S. Dept. Agr. Misc. Publ. No. 200 (1935). 4. Ohwi, J., Bot. Mag. Tokyo 55: 350-362 (1941). 5. - Acta Phytotax. Geobot. 11: 145-193 (1942) (in Japanese). 6. Pilger, R., Bot. Jb. 76: 281-384 (1954). 7. Tateoka. T., Jour. Jap. Bot. 31: 1-5 (1956a) (in Japanese). $8 . \longrightarrow$ Ibid. 31: 84-90 (1956b) (in Japanese). $9 . \quad$, Ibid. 31: 179186 (1956c) (in Japanese). $10 . \longrightarrow$, Ibid. $31: 241-248$ (1956d) (in Japanese) 11. — Ibid. $31:$ 267-272 (1956e) (in Japanese). $12 . \simeq$ Ibid. 31:326-332 (1956f) (in Japanese). 